\title{
Fumarase From Cyanidioschyzon merolae Stably Shows High Catalytic Activity for Fumarate Hydration Under High Temperature Conditions
}

\author{
Shoki Ito, Kaori Iwazumi, Haruna Sukigara and Takashi Osanai* \\ School of Agriculture, Meiji University, Kawasaki, Japan
}

Fumarases (Fums) catalyze the reversible reaction converting fumarate to L-malate. There are two kinds of Fums: Class I and II. Thermostable Class II Fums, from mesophilic microorganisms, are utilized for industrial L-malate production. However, the low thermostability of these Fums is a limitation in industrial L-malate production. Therefore, an alternative Class II Fum that shows high activity and thermostability is required to

OPEN ACCESS

Edited by:

Weiwen Zhang,

Tianjin University, China

Reviewed by:

Guodong Luan,

Qingdao Institute of Bioenergy and

Bioprocess Technology (CAS), China

Xiaoming Tan,

Hubei University, China

Stefan Rokem,

Hebrew University of Jerusalem,

Israel

${ }^{*}$ Correspondence:

Takashi Osana

tosanai@meiji.ac.jp

Specialty section:

This article was submitted to

Microbiotechnology,

a section of the journal

Frontiers in Microbiology

Received: 11 May 2020

Accepted: 18 August 2020 Published: 16 September 2020

Citation:

Ito S, Iwazumi K, Sukigara $H$ and Osanai $T$ (2020) Fumarase From Cyanidioschyzon merolae Stably Shows High Catalytic Activity for

Fumarate Hydration Under High Temperature Conditions.

Front. Microbiol. 11:560894. doi: 10.3389/fmicb.2020.560894 overcome this drawback. Thermophilic microalgae and cyanobacteria can use carbon dioxide as a carbon source and are easy to cultivate. Among them, Cyanidioschyzon merolae and Thermosynechococcus elongatus are model organisms to study cell biology and structural biology, respectively. We biochemically analyzed Class II Fums from C. merolae (CmFUM) and T. elongatus (TeFum). Both CmFUM and TeFum preferentially catalyzed fumarate hydration. The catalytic activity of $\mathrm{CmFUM}$ for fumarate hydration in the optimum conditions $\left(52^{\circ} \mathrm{C}\right.$ and $\left.\mathrm{pH} 7.5\right)$ is higher compared to those of Class II Fums from other organisms and TeFum. Thermostability tests of $C m F U M$ revealed that $\mathrm{CmFUM}$ showed higher thermostability than those of Class II Fums from other microorganisms. The yield of L-malate obtained from fumarate hydration catalyzed by CmFUM was 75-81\%. In summary, CmFum has suitable properties for efficient L-malate production.

Keywords: fumarase, tricarboxylic acid cycle, L-malate, microalgae, cyanobacteria

\section{INTRODUCTION}

Fumarase, or fumarate hydratase (EC 4.2.1.2; hereafter referred to as Fum) is one of the enzymes of the tricarboxylic acid (TCA) cycle and catalyzes the reversible hydration/dehydration reaction of fumarate to L-malate. Based on biochemical analyses of isozymes of Fum from Escherichia coli, these enzymes are divided into two biochemically distinct classes named Class I and II (Woods et al., 1988). Amino acid sequence analysis revealed that there is no overall homology between Class I and II Fums (Woods et al., 1988). There is an approximately 40\% difference between the amino acid sequences of the Class II Fums from eukaryotes and prokaryotes (Sacchettini et al., 1988). Class I Fums are thermolabile homo-dimeric enzymes, whereas Class II Fums are thermostable homo-tetrameric enzymes (Woods et al., 1988).

L-Malate is used in various industrial applications such as acidulants, flavor enhancers, color fixatives, medicines, and antimicrobial agents (Liu et al., 2017). Fum has been used as a biocatalyst for industrial L-malate production (Liu et al., 2017). Class II Fum from the mesophilic bacterium Corynebacterium glutamicum (Brevibacterium flavum) can be used for L-malate production. 
L-Malate production using the C. glutamicum Fum requires heat treatment at $40-60^{\circ} \mathrm{C}$ for $10-300 \mathrm{~min}$ to repress by-product succinate formation because it is hard to separate succinate from L-malate (Terasawa et al., 1990). Thus, Fums used for L-malate production must maintain high activity after heat treatment. However, the stability of Class II Fums from mesophilic microorganisms, including C. glutamicum, is insufficient at these temperatures (Takata et al., 1983; Keruchenko et al., 1992; Lin et al., 2007, 2018; Song et al., 2011). Class II Fum from the highly thermophilic bacterium Thermus thermophilus shows high thermostability, with an optimum temperature of $85^{\circ} \mathrm{C}$ (Mizobata et al., 1998). However, this enzyme is not economically viable for $\mathrm{L}$-malate production. The first reason is that maintaining the reaction temperature at $85^{\circ} \mathrm{C}$ is energy intensive. Second, the activity of this enzyme is lower than those of other Class II Fums from mesophilic bacteria such as C. glutamicum (Lin et al., 2018). Thus, natural Class II Fums from culturable microorganisms, which have suitable enzymatic properties for L-malate production, have not yet been identified. Previously, a Class II Fum from C. glutamicum was modified by introducing three mutations to enhance thermostability (Lin et al., 2018).

Eukaryotic microalgae and cyanobacteria are microorganisms that perform oxygenic photosynthesis and can use carbon dioxide as the sole carbon source. In recent years, biotechnological applications of thermophilic microalgae and cyanobacteria have been gaining attention because these organisms do not compete for food sources and their growth at high temperatures prevents contamination with other microorganisms (Patel et al., 2019). The entire genomic sequences of the hot-spring red alga Cyanidioschyzon merolae and the hot-spring cyanobacterium, Thermosynechococcus elongatus are known (Ohta et al., 1998, 2003; Nakamura et al., 2002; Matsuzaki et al., 2004; Nozaki et al., 2007) and they can be easily cultivated. C. merolae is a eukaryote that has the simplest cellular structure and has been primarily used for cell biological studies so far (Kuroiwa et al., 1998). T. elongatus is the simplest photosynthetic organism that displays thermostability and therefore has been used for structural analyses of the photosynthetic system (Murray et al., 2007; Laughlin et al., 2019; Schuller et al., 2019; Zhang et al., 2019). However, biochemical analyses of their enzymes of primary metabolic pathways, such as the TCA cycle, have not yet been performed. Additionally, Fums from thermophilic microalgae and cyanobacteria, have not been biochemically characterized. Genome sequencing revealed that both C. merolae and T. elongatus have a sole Class II Fum as a fumarase (Nakamura et al., 2002; Matsuzaki et al., 2004).

In this study, we biochemically characterized Fums from C. merolae (CmFUM) and T. elongatus (TeFum) and examined whether these Fums have suitable enzymatic properties for L-malate production.

\section{MATERIALS AND METHODS}

\section{Preparation of Expression Constructs of CmFUM and TeFum}

The genomic regions containing CmFUM (CMD058C) and TeFum (tll1534) with N-terminal BamHI and C-terminal XhoI sites were commercially synthesized by Eurofin Genomics Japan (Tokyo, Japan). Codon usage was optimized for E. coli. The synthesized DNA fragments were cloned into the BamHI-XhoI site of the pGEX6P-1 vector (GE Healthcare, Little Chalfont, United Kingdom).

\section{Purification of CmFUM and TeFum}

Glutathione-S-transferase (GST)-tagged CmFUM and TeFum were purified using affinity chromatography as described with a few alterations (Takeya et al., 2017). The CmFUM and TeFum constructs were transformed individually into E. coli BL21 (DE3) competent cells (BioDynamics Laboratory Inc., Tokyo, Japan). BL21 (DE3) cells were cultivated overnight in $1.5 \mathrm{~L} \mathrm{LB}$ media at $30^{\circ} \mathrm{C}$ with shaking $(150 \mathrm{rpm})$. During the cultivation of BL21 (DE3) cells, the expression of GST-tagged Fums was induced by $0.01 \mathrm{mM}$ isopropyl $\beta$-D-1-thiogalactopyranoside (Wako Chemicals, Osaka, Japan). The cells were collected by repeated centrifugation $\left(5,800 \mathrm{~g}, 2 \mathrm{~min}, 25^{\circ} \mathrm{C}\right)$ and transferred to $50 \mathrm{ml}$ tubes containing PBS-T (1.37 M NaCl, $27 \mathrm{mM} \mathrm{KCl,} 81 \mathrm{mM}$ $\mathrm{Na}_{2} \mathrm{HPO}_{4} \cdot 12 \mathrm{H}_{2} \mathrm{O}, 14.7 \mathrm{mM} \mathrm{KH_{2 }} \mathrm{PO}_{4}$, and $0.05 \%$ Tween-20). To dissolve the GST-tagged Fums in PBS-T, the cells were sonicated for $200 \mathrm{~s}$ at $20 \%$ intensity (model VC-750, EYELA, Tokyo, Japan). After centrifugation $\left(14,200 \mathrm{~g}, 15 \mathrm{~min}, 4^{\circ} \mathrm{C}\right), 800 \mu \mathrm{l}$ of glutathione-Sepharose 4B resin (GE Healthcare Japan, Tokyo, Japan) was added to the supernatant containing the GST-tagged Fums. To bind the GST-tagged Fums to glutathione-Sepharose $4 \mathrm{~B}$ resin, the mixture was shaken for $1 \mathrm{~h}$ on ice. After centrifugation $\left(5,800 \mathrm{~g}, 2 \mathrm{~min}, 4^{\circ} \mathrm{C}\right)$ to remove the supernatant, the resin was washed three and five times using $3 \mathrm{ml}$ and $700 \mu \mathrm{l}$ of PBS-T, respectively, to remove non-specific proteins. Thereafter, the GST-tagged Fums were eluted five times using $500 \mu \mathrm{l}$ of GST elution buffer $(50 \mathrm{mM}$ Tris- $\mathrm{HCl}(\mathrm{pH} 8.0)$ and $10 \mathrm{mM}$ reduced glutathione) and concentrated using a VivaSpin 500 MWCO 50,000 device (Sartorius, Göttingen, Germany). The protein concentration was calculated using a Pierce BCA Protein Assay Kit (Thermo Scientific, Rockford, IL).

\section{Enzyme Assays for CmFUM and TeFum}

The $1 \mathrm{ml}$ assay solution of CmFUM contains $100 \mathrm{mM}$ Tris- $\mathrm{HCl}$ [pH 7.5 (fumarate hydration) or 8.5 (L-malate dehydration)], 5 pmol CmFUM, and various concentrations of fumarate or L-malate. The $1 \mathrm{ml}$ assay solution of TeFum contains $100 \mathrm{mM}$ Tris- $\mathrm{HCl}[\mathrm{pH} \quad 7.0$ (fumarate hydration) or 7.5 (L-malate dehydration)], $30 \mathrm{pmol} \mathrm{TeFum,} \mathrm{and} \mathrm{various} \mathrm{concentrations} \mathrm{of}$ fumarate or L-malate. The assay solution of $C m F U M$ and TeFum before adding substrates was incubated for $5 \mathrm{~min}$ at $52^{\circ} \mathrm{C}$ and $50^{\circ} \mathrm{C}$, respectively. Thereafter, various concentrations of fumarate or L-malate were added to the assay solution to start the reaction. The activities of $\mathrm{CmFUM}$ and TeFum were calculated by monitoring the changes in absorbance at $A_{240}$ using a Shimadzu UV-1850 (Shimadzu, Kyoto, Japan). One unit of Fum activity was defined as the amount of Fum that converts $1 \mu \mathrm{mol}$ fumarate or $\mathrm{L}$-malate per min. The maximum reaction velocity $\left(V_{\max }\right)$ and $K_{\mathrm{m}}$ (substrate concentration at $\left.50 \% V_{\max }\right)$ of $\mathrm{CmFUM}$ and TeFum were calculated by curve fitting of the Michaelis-Menten equation using the Kaleida 
Graph ver. 4.5. The $k_{\text {cat }}$ (turnover number) of $C m F U M$ and $\mathrm{TeFum}$ was calculated from their $V_{\max }$ values.

\section{Thermostability Measurements of CmFUM}

Thermostability measurements of $\mathrm{CmFUM}$ were performed as described previously (Lin et al., 2018). The $1 \mathrm{ml}$ assay solution of $\mathrm{CmFUM}$ contains $100 \mathrm{mM}$ Tris- $\mathrm{HCl}$ (pH 7.5), 5 pmol CmFUM, and $0.5 \mathrm{mM}$ fumarate. To measure the $T_{50}{ }^{15}$ (temperature where the activity becomes $50 \%$ after heat treatment for $15 \mathrm{~min}$ ), the assay solution before adding fumarate was pre-incubated at each temperature for $15 \mathrm{~min}$. Thereafter, the enzyme assay described in the previous section was performed. To measure $t_{1 / 2}$ (time where the activity becomes $50 \%$ after heat treatment), the assay solution before adding fumarate was preincubated at $50^{\circ} \mathrm{C}$ for each timepoint and then immediately cooled on ice for $1 \mathrm{~min}$. Thereafter, the enzyme assay described in the previous section was performed.

\section{Analysis of the Reaction Catalyzed by CmFum When Using 200 mM Fumarate as a Substrate}

The $500 \mu \mathrm{l}$ assay solution contains $100 \mathrm{mM}$ Tris- $\mathrm{HCl}(\mathrm{pH} 7.5)$, $500 \mathrm{pmol} \mathrm{CmFUM}$, and $200 \mathrm{mM}$ disodium fumarate. The assay solution before adding fumarate was pre-incubated for $5 \mathrm{~min}$ at $52^{\circ} \mathrm{C}$. Thereafter, fumarate which was also pre-incubated for $5 \mathrm{~min}$ at $52^{\circ} \mathrm{C}$ was added to the assay solution and the reaction was started at $52^{\circ} \mathrm{C}$. After the reaction for $5,10,20,30,40$, 50, and $60 \mathrm{~min}, 50 \mu \mathrm{l}$ of the assay solution was collected and the reaction was stopped by $100 \mathrm{mM} \mathrm{HCl}$. The samples were analyzed by high-performance liquid chromatography (HPLC) using an LC-2000Plus System (JASCO, Tokyo, Japan). Organic acids were quantified using $0.2 \mathrm{mM}$ bromothymol blue in $15 \mathrm{mM}$ sodium phosphate buffer; peaks were detected at $445 \mathrm{~nm}$, as described previously (Osanai et al., 2015).

\section{Analysis of the Reaction Catalyzed by CmFum When Using $1 \mathrm{M}$ Fumarate as a Substrate}

The $100 \mu \mathrm{l}$ assay solution containing $100 \mathrm{mM}$ Tris- $\mathrm{HCl}(\mathrm{pH}$ 7.5), $50 \mathrm{pmol} C m \mathrm{FUM}$, and $1 \mathrm{M}$ disodium fumarate was incubated at $52^{\circ} \mathrm{C}$ for $24 \mathrm{~h}$. Thereafter, $\mathrm{HCl}$ was added to the assay solution to be $100 \mathrm{mM}$. The sample is analyzed by HPLC using an LC-2000Plus System (JASCO, Tokyo, Japan). Organic acids were quantified using $0.2 \mathrm{mM}$ bromothymol blue in $15 \mathrm{mM}$ sodium phosphate buffer and peaks were detected at $445 \mathrm{~nm}$, as described previously (Osanai et al., 2015).

\section{RESULTS}

\section{Biochemical Properties of CmFUM and TeFum}

To characterize the biochemical properties of CmFUM and TeFum, we purified $\mathrm{CmFUM}$ and TeFum as GST-tagged proteins using affinity chromatography (Figure 1). We first measured their activities using fumarate as a substrate (hereafter "the activity for fumarate") and L-malate as a substrate (hereafter "the activity for L-malate") at different temperatures and $\mathrm{pH}$ values (Figure 2). CmFUM showed the highest activity for both substrates at $52^{\circ} \mathrm{C}$ (Figure 2A). $\mathrm{CmFUM}$ showed the highest activity for fumarate and L-malate at $\mathrm{pH} 7.5$ and 8.5, respectively, (Figure 2B). We then set the measurement conditions of $\mathrm{CmFUM}$ activities for fumarate at $52^{\circ} \mathrm{C}$ and $\mathrm{pH} 7.5$ and for $\mathrm{L}$-malate at $52^{\circ} \mathrm{C}$ and $\mathrm{pH}$ 8.5. TeFum consistently showed high activity for both substrates at $45-55^{\circ} \mathrm{C}$ (Figure 2C) and showed the highest activity for fumarate and $\mathrm{L}$-malate at $\mathrm{pH}$ 7.0 and 7.5, respectively (Figure 2D). We then set the measurement conditions of TeFum activities for fumarate at

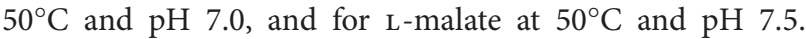

To calculate the kinetic parameters of $\mathrm{CmFUM}$ and $\mathrm{TeFum}$, the enzymatic activities were measured at different substrate concentrations (Figure 3). The saturation curves of $\mathrm{CmFUM}$ and TeFum for both substrates were not sigmoidal but hyperbolic (Figure 3) and the kinetic parameters of $\mathrm{CmFUM}$ and TeFum were calculated using the Michaelis-Menten equation (Table 1). The $K_{\mathrm{m}}$ (substrate concentration at $50 \% V_{\max }$ ) and $k_{\text {cat }}$ (turnover number) of $C m$ FUM for fumarate were $0.27 \pm 0.05 \mathrm{mM}$ and $235 \pm 22 \mathrm{~s}^{-1}$, respectively (Table 1 ). The $K_{\mathrm{m}}$ and $k_{\text {cat }}$ of $C m \mathrm{FUM}$ for L-malate were $1.49 \pm 0.12 \mathrm{mM}$ and $244 \pm 6 \mathrm{~s}^{-1}$, respectively (Table 1). The $k_{\text {cat }} / K_{\mathrm{m}}$ (catalytic efficiency) of $\mathrm{CmFUM}$ for fumarate $\left(872 \pm 68 \mathrm{~s}^{-1} \mathrm{mM}^{-1}\right)$ was 5.3 -fold higher than that for L-malate $\left(164 \pm 9 \mathrm{~s}^{-1} \mathrm{mM}^{-1}\right.$; Table 1). The $K_{\mathrm{m}}$ and $k_{\text {cat }}$ of TeFum for fumarate were $0.14 \pm 0.02 \mathrm{mM}$ and $37 \pm 2 \mathrm{~s}^{-1}$, respectively (Table 1). The $K_{\mathrm{m}}$ and $k_{\text {cat }}$ of TeFum for L-malate were $0.20 \pm 0.01 \mathrm{mM}$ and $15 \pm 0.3 \mathrm{~s}^{-1}$, respectively, (Table 1). The $k_{\text {cat }} / K_{\mathrm{m}}$ of TeFum for fumarate $\left(278 \pm 23 \mathrm{~s}^{-1} \mathrm{mM}^{-1}\right)$ was 3.7-fold higher than that for L-malate $\left(76 \pm 1 \mathrm{~s}^{-1} \mathrm{mM}^{-1}\right)$.

Succinite, citrate, and pyruvate act as effectors of Class II Fums from higher plant Arabidopsis thaliana (mitochondrial Fum; Zubimendi et al., 2018) and mesophilic cyanobacterium

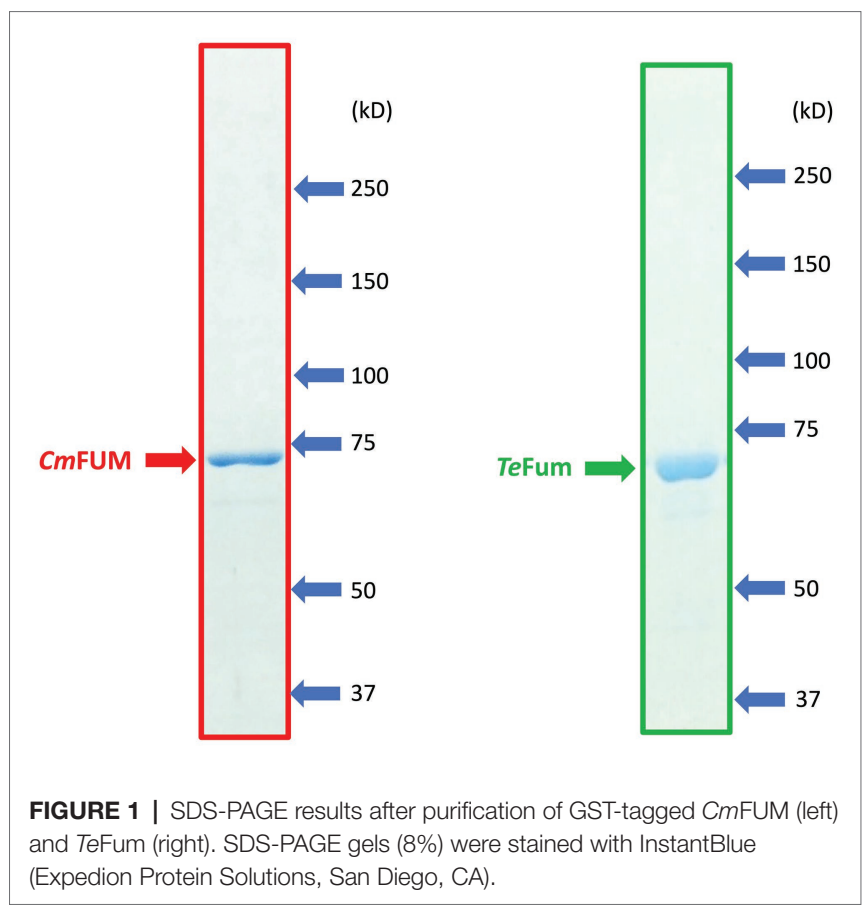



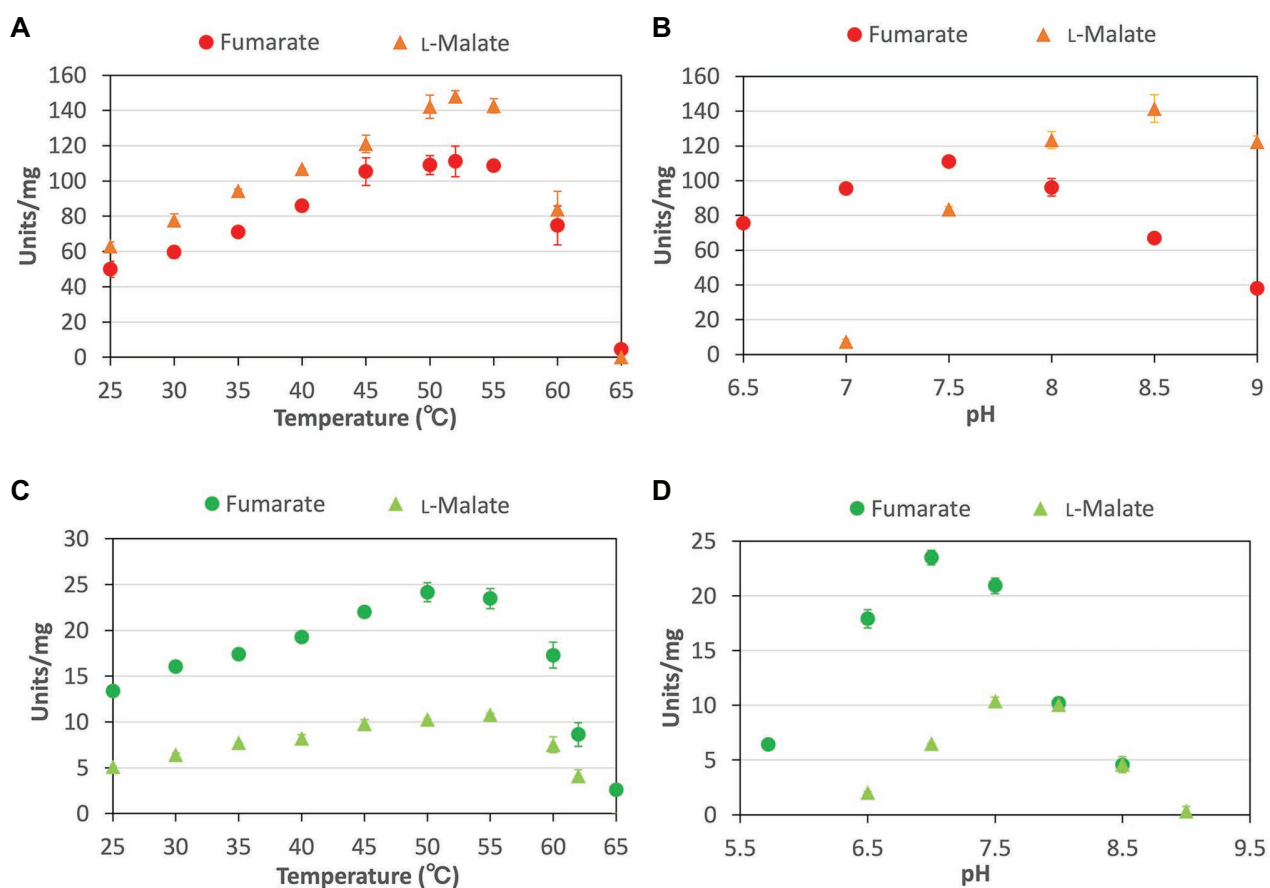

FIGURE 2 | Temperature and $\mathrm{pH}$ dependence of CmFUM and TeFum (A) CmFUM activity at each temperature. The measurements using fumarate and L-malate as substrates were performed at $\mathrm{pH} 7.5$ and 8.5 , respectively. The concentrations of fumarate and L-malate were 0.5 and $5 \mathrm{mM}$, respectively. (B) CmFUM activity at each $\mathrm{pH}$ level. The measurements were performed at $52^{\circ} \mathrm{C}$. The concentrations of fumarate and L-malate were 0.5 and $5 \mathrm{mM}$, respectively. (C) TeFum activity at each temperature. The measurements using fumarate and L-malate as substrates were performed at $\mathrm{pH} 7.0$ and 7.5 , respectively. The concentrations of fumarate and L-malate were 0.5 and $1 \mathrm{mM}$, respectively. (D) TeFum activity at each pH level. The measurements were performed at $50^{\circ} \mathrm{C}$. The concentrations of fumarate and L-malate were 0.5 and $1 \mathrm{mM}$, respectively. The circles and triangles in Figure 2 indicate the activity using fumarate and L-malate as substrates, respectively. All data in Figure 2 indicate the mean \pm SD obtained from three independent experiments.

Synechocystis sp. PCC 6803 (hereafter Synechocystis 6803; Katayama et al., 2019). We examined the effects of the three organic acids on CmFUM and TeFum activities (Figure 4). The three organic acids decreased the CmFUM activity for fumarate (Figure 4A). Succinate decreased the CmFUM activity for L-malate (Figure 4A). Succinate and citrate decreased the TeFum activity for fumarate (Figure 4B). In contrast, pyruvate increased the TeFum activity for fumarate (Figure 4B). The three organic acids decreased the TeFum activity for L-malate (Figure 4B).

\section{Further Biochemical Analyses of CmFUM for L-Malate Production}

Higher activity and specificity for fumarate were seen in CmFUM than in TeFum (Table 1). Therefore, we examined the important enzymatic property for L-malate production, thermostability of $\mathrm{CmFUM}$ (Figure 5). The residual activity of $\mathrm{CmFUM}$ for fumarate after heat treatment for $15 \mathrm{~min}$ decreased linearly depending on the heat treatment temperature within the range of $53-60^{\circ} \mathrm{C}$ (Figure 5A). The $T_{50}{ }^{15}$ (temperature where the activity becomes $50 \%$ after heat treatment for $15 \mathrm{~min}$ ) was calculated as $57.3^{\circ} \mathrm{C}$ using a linear equation (Figure 5A). In addition, the residual activity of $\mathrm{CmFUM}$ for fumarate after heat treatment at $50^{\circ} \mathrm{C}$ decreased linearly depending on the length of heat treatment (Figure 5B).
The $t_{1 / 2}$ (time where the activity becomes $50 \%$ after heat treatment) at $50^{\circ} \mathrm{C}$ was calculated as 507 min using a linear equation (Figure 5B).

Additionally, we examined the effects of metal cations and buffer solutions on CmFUM activity for fumarate and determined the condition where CmFUM shows the highest activity for fumarate (Figure 6). CmFUM activity for fumarate did not change in the presence of monovalent and divalent metal cations (Figure 6A). CmFUM activity for fumarate in HEPES$\mathrm{NaOH}$ buffer was slightly lower than that in Tris- $\mathrm{HCl}$ buffer (Figure 6B). CmFUM activity for fumarate in each of the other three buffers tested was not significantly different from that in Tris-HCl buffer (Figure 6B).

Finally, in the optimum conditions of $C m$ FUM, we analyzed the reaction catalyzed by $C m$ FUM using high concentrations (industrial level) of fumarate as a substrate. CmFUM showed enzymatic activity in the presence of $200 \mathrm{mM}$ and $1 \mathrm{M}$ fumarate (Figure 7). When using $200 \mathrm{mM}$ fumarate as a substrate of $\mathrm{CmFUM}$, the yield of $\mathrm{L}$-malate increased depending on reaction time, and the yield in an equilibrium state was 75\% (Figure 7A). Also, the yield of L-malate when using $1 \mathrm{M}$ fumarate as a substrate of $\mathrm{CmFUM}$ was $81 \%$ (Figure $7 \mathrm{~B}$ ). An unwanted by-product in L-malate production, succinate was not detected in all samples using high concentrations of fumarate as a substrate. 

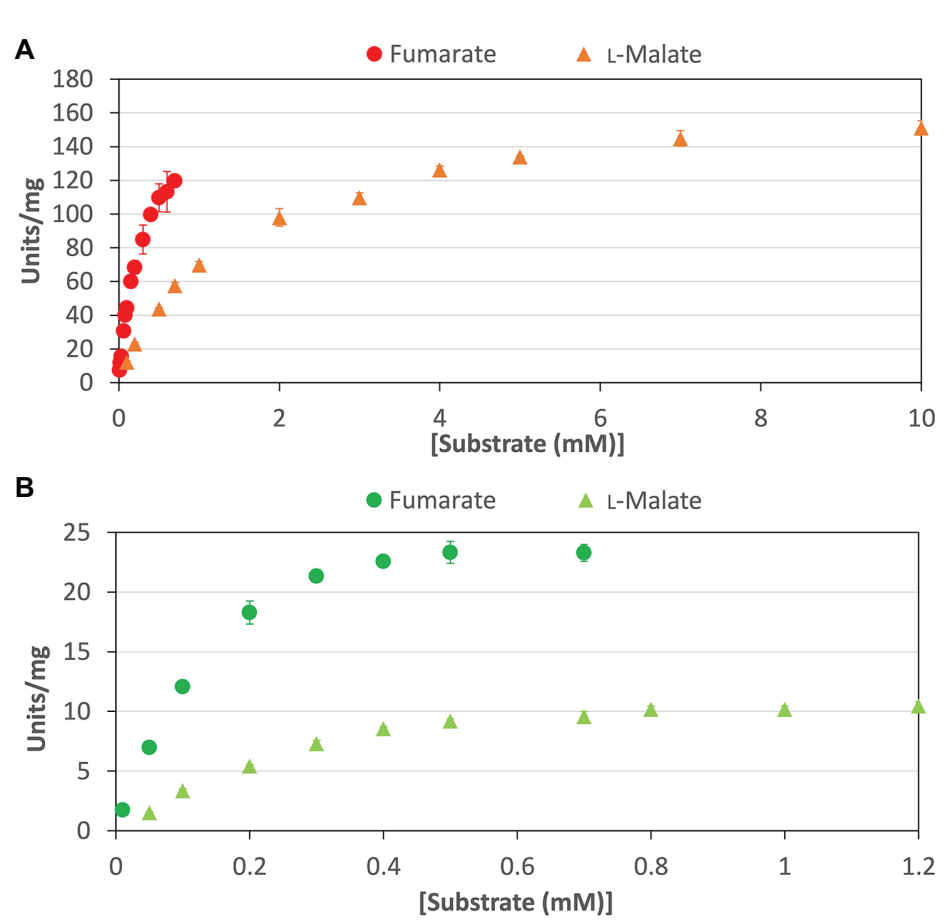

FIGURE 3 | Saturation curves of CmFUM and TeFum for substrates. (A) Saturation curves of CmFUM for fumarate (circles) and L-malate (triangles). The measurements using fumarate and L-malate as substrates were performed at $52^{\circ} \mathrm{C}$ and $\mathrm{pH} 7.5$, and $52^{\circ} \mathrm{C}$ and $\mathrm{pH} 8.5$, respectively. (B) Saturation curves of TeFum for fumarate (circles) and L-malate (triangles). The measurements using fumarate and L-malate as substrates were performed at $50^{\circ} \mathrm{C}$ and $\mathrm{pH} 7.0$, and $50^{\circ} \mathrm{C}$ and $\mathrm{pH}$ 7.5, respectively. All the data in Figure 3 indicate the mean \pm SD obtained from three independent experiments.

TABLE 1 | Kinetic parameters of CmFUM and TeFum.

\begin{tabular}{|c|c|c|c|c|c|}
\hline Enzyme & Substrate & $K_{\mathrm{m}}(\mathrm{mM})$ & $\boldsymbol{k}_{\text {cat }}\left(\mathbf{s}^{-1}\right)$ & $k_{\mathrm{cat}} / K_{\mathrm{m}}\left(\mathbf{s}^{-1} \mathrm{mM}^{-1}\right)$ & $\begin{array}{c}\text { Ratio } \boldsymbol{k}_{\mathrm{cat}} / \boldsymbol{K}_{\mathrm{m}} \\
\text { (fumarate/L-malate) }\end{array}$ \\
\hline CmFUM & $\begin{array}{l}\text { Fumarate } \\
\text { L-Malate }\end{array}$ & $\begin{array}{l}0.27 \pm 0.05 \\
1.49 \pm 0.12\end{array}$ & $\begin{array}{l}235 \pm 22 \\
244 \pm 6\end{array}$ & $\begin{array}{l}872 \pm 68 \\
164 \pm 9\end{array}$ & 5.3 \\
\hline TeFum & $\begin{array}{l}\text { Fumarate } \\
\text { L-Malate }\end{array}$ & $\begin{array}{l}0.14 \pm 0.02 \\
0.20 \pm 0.01\end{array}$ & $\begin{array}{l}37 \pm 2 \\
15 \pm 0.3\end{array}$ & $\begin{array}{c}278 \pm 23 \\
76 \pm 1\end{array}$ & 3.7 \\
\hline
\end{tabular}

The measurement conditions are described in the legend of Figure 3. Data represent the mean \pm SD obtained from three independent data points.

\section{DISCUSSION}

For the first time, Fums from a thermophilic microalga and cyanobacterium were purified and biochemically characterized. The optimum temperatures for the enzymatic activity of $\mathrm{CmFUM}$ $\left(52^{\circ} \mathrm{C}\right)$ and $\mathrm{TeFum}\left(45-55^{\circ} \mathrm{C}\right)$ were higher than those of Class II Fums from mesophilic microorganisms $\left(30-45^{\circ} \mathrm{C}\right.$, four species: Streptomyces coelicolor, Rhizopus oryzae, Synechocystis 6803, and Streptomyces lividans; Lin et al., 2007; Song et al., 2011; Su et al., 2014; Katayama et al., 2019), similar to that of Class II Fum from Streptomyces thermovulgaris $\left(50^{\circ} \mathrm{C}\right.$; Lin et al., 2007), and lower than those of Class II Fums from T. thermophilus $\left(85^{\circ} \mathrm{C}\right.$; Mizobata et al., 1998) and the thermophilic archaebacterium Sulfolobus solfataricus $\left(85^{\circ} \mathrm{C}\right.$; Puchegger et al., 1990; Figures 2A,C). C. merolae grows optimally at $46^{\circ} \mathrm{C}$ (Moriyama et al., 2008), suggesting that $\mathrm{CmFUM}$ stably shows high activity at the optimum growth temperature. T. elongatus rapidly grows in the range of
50-60 C (Yamaoka et al., 1978). In T. elongatus, the activities of photosynthesis and entire electron transport were dependent on temperature and high in the range of $50-60^{\circ} \mathrm{C}$ (Yamaoka et al., 1978). It is suggested that TeFum also becomes active at these growth temperatures. The optimum $\mathrm{pH}$ for $\mathrm{CmFUM}(\mathrm{pH}$ 7.5 for fumarate hydration; $\mathrm{pH} 8.5$ for L-malate dehydration) and TeFum (pH 7.0 for fumarate hydration; $\mathrm{pH} 7.5$ for L-malate dehydration) were approximately the same as those of Class II Fums from other organisms ( $\mathrm{pH}$ 6.5-8.5, seven species: R. oryzae, Synechocystis 6803, Saccharomyces cerevisiae, S. solfataricus, C. glutamicum, A. thaliana, and Homo sapience; Puchegger et al., 1990; Keruchenko et al., 1992; Genda et al., 2006; Song et al., 2011; Zubimendi et al., 2018; Ajalla Aleixo et al., 2019; Katayama et al., 2019; Figures 2B,D). Intercellular $\mathrm{pH}$ of $\mathrm{C}$. merolae and cyanobacteria is maintained near neutral where $\mathrm{CmFUM}$ and TeFum show enzymatic activities (Coleman and Colman, 1981; Zenvirth et al., 1985; Mangan et al., 2016). Unlike Class II 

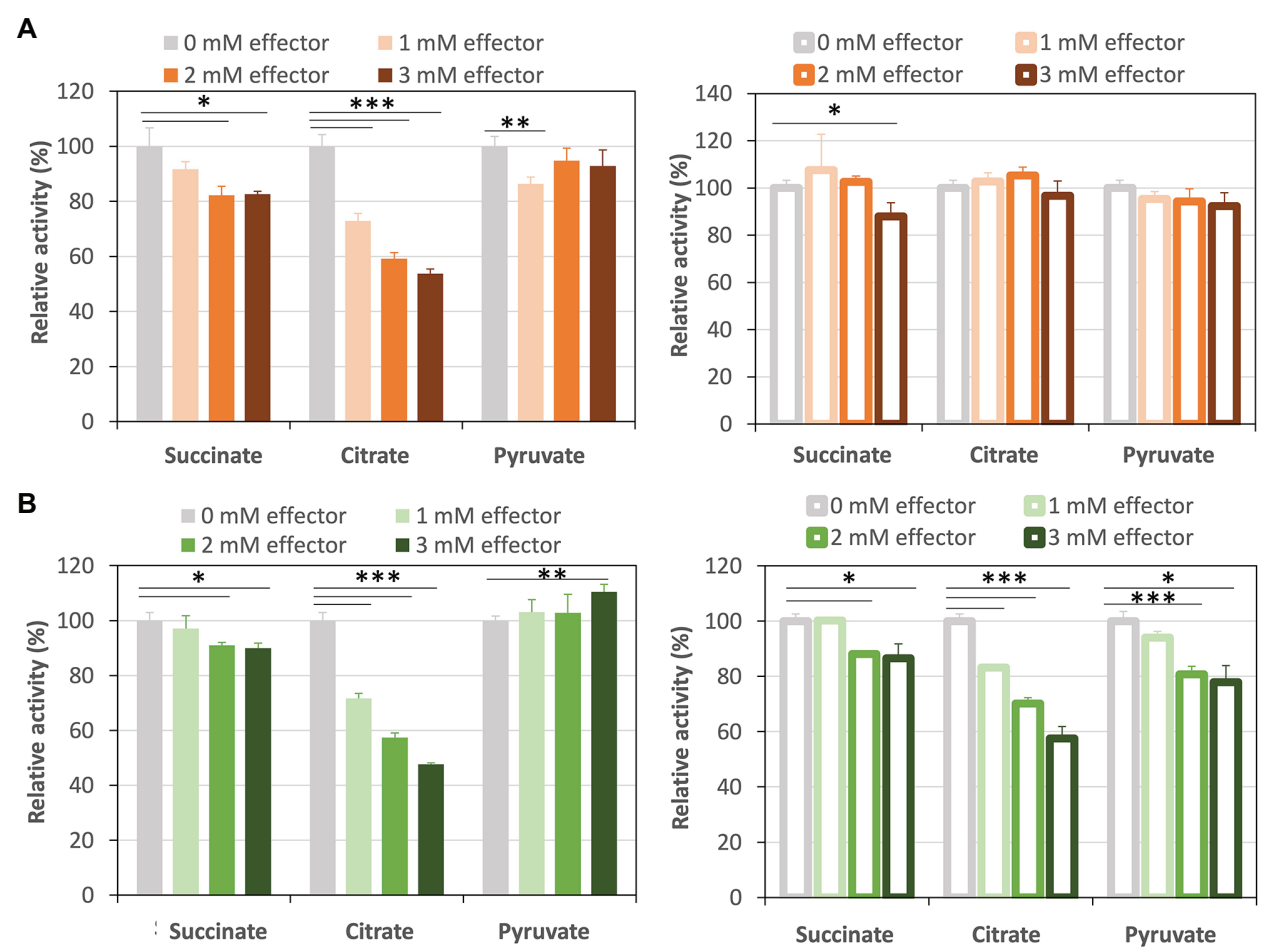

FIGURE 4 | Effects of three organic acids on CmFUM and TeFum activity. (A) CmFUM activity using fumarate (left) and L-malate (right) as a substrate in the presence of organic acids. The measurements using fumarate and L-malate as substrates were performed at $52^{\circ} \mathrm{C}$ and $\mathrm{pH} 7.5$, and $52^{\circ} \mathrm{C}$ and $\mathrm{pH} 8.5$, respectively. The concentrations of fumarate and L-malate were the $K_{\mathrm{m}}$ values of CmFUM, $0.27 \mathrm{mM}$ and $1.49 \mathrm{mM}$, respectively. (B) TeFum activity using fumarate (left) and Lmalate (right) as a substrate in the presence of organic acids. The measurements using fumarate and $\mathrm{L}$-malate as substrates were performed at $50^{\circ} \mathrm{C}$ and $\mathrm{pH} 7.0$, and $50^{\circ} \mathrm{C}$ and $\mathrm{pH} 7.5$, respectively. The concentrations of fumarate and L-malate were the $K_{\mathrm{m}}$ values of TeFum, $0.14 \mathrm{mM}$ and $0.20 \mathrm{mM}$, respectively. All organic acids used as effectors were sodium salts. All the enzymatic activities in Figure 4 are represented by relative activities and the activity in the absence of effectors (gray bar) was set at 100\%. All data in Figure 4 indicate the mean \pm SD obtained from three independent experiments. All asterisks in Figure 4 indicate statistically significant differences between the absence and presence of the effector (Welch's $t$-test; ${ }^{*} p<0.05,{ }^{* * *} p<0.01,{ }^{* * * *} p<0.005$ ). All $p$-values obtained from Welch's t-test in (A,B) are listed in Supplementary Tables $\mathbf{S 1}$ and $\mathbf{S 2}$, respectively.

A

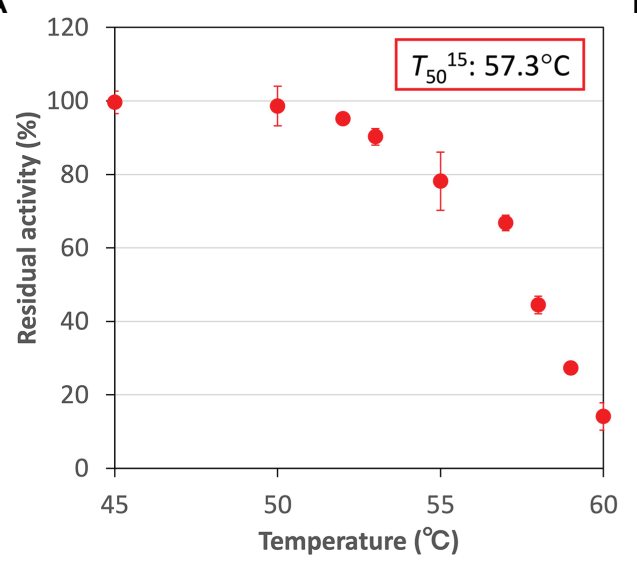

B

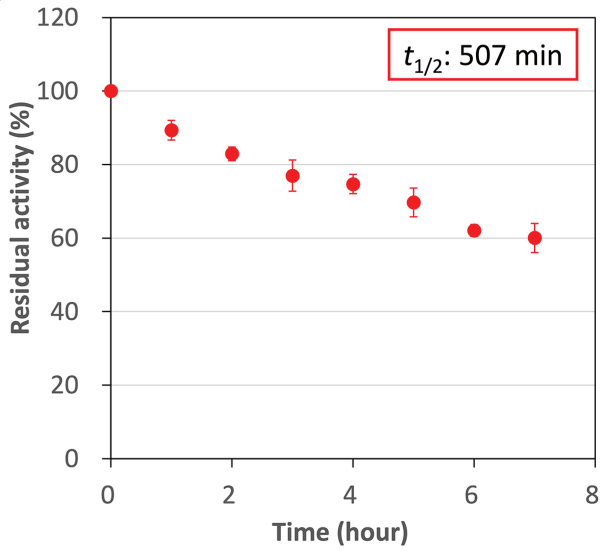

FIGURE 5 | Thermostability of CmFUM. (A) CmFUM activity after heat treatment at each temperature for 15 min. The measurements were performed at pH 7.5 . The concentration of fumarate was $0.5 \mathrm{mM}$. The $T_{50}{ }^{15}$ was calculated using a linear equation obtained from six values (53-60 ${ }^{\circ} \mathrm{C}$ ). (B) $\mathrm{CmFUM}$ activity after heat treatment at $50^{\circ} \mathrm{C}$ for each time-point. The measurements were performed at $\mathrm{pH} 7.5$. The concentration of fumarate was $0.5 \mathrm{mM}$. The $t_{1 / 2}$ was calculated using a linear equation obtained from all the values. All the enzymatic activities in Figure 5 are represented by residual activities, and the activity without heat-treatment was set at $100 \%$. All the data in Figure 5 show the mean \pm SD obtained from three independent experiments. 


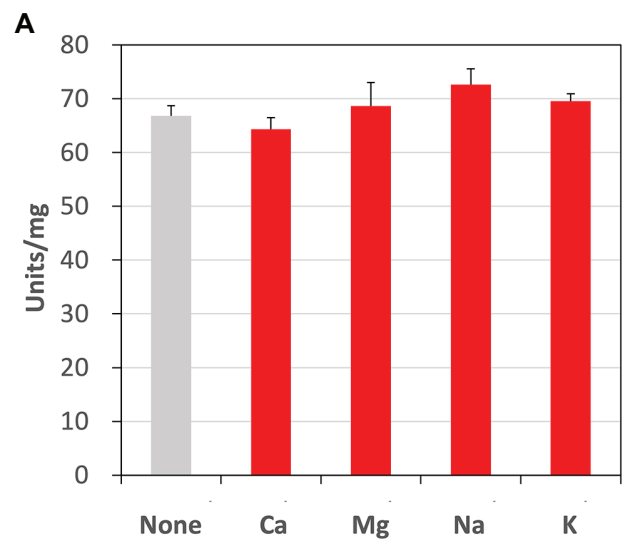

B

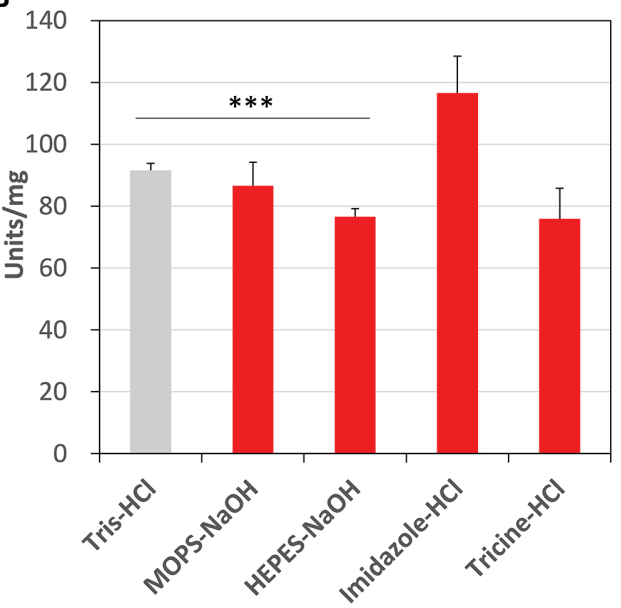

FIGURE 6 | Effects of metal cations and buffer solutions on CmFUM activity. (A) CmFUM activity in the presence of $5 \mathrm{mM}$ metal cations. The measurement was performed at $52^{\circ} \mathrm{C}$ and $\mathrm{pH}$ 7.5. The concentration of fumarate was the $K_{\mathrm{m}}$ of $\mathrm{CmFUM}, 0.27 \mathrm{mM}$. Ca: $\mathrm{CaCl}_{2}, \mathrm{Mg}: \mathrm{MgCl}_{2}, \mathrm{Na:} \mathrm{NaCl}, \mathrm{K}: \mathrm{KCl}$ (B) CmFUM activity in $100 \mathrm{mM}$ buffer solutions. The measurement was performed at $52^{\circ} \mathrm{C}$ and pH 7.5. The concentration of fumarate was $0.5 \mathrm{mM}$. The asterisk indicates a statistically significant difference between the activity in Tris-HCl and HEPES-NaOH buffer (Welch's $t$-test; $\left.{ }^{* * * *} p<0.005\right)$. All $p$-values obtained from Welch's $t$-test in $(\mathbf{A}, \mathbf{B})$ are listed in Supplementary Tables S3 and S4, respectively.

A

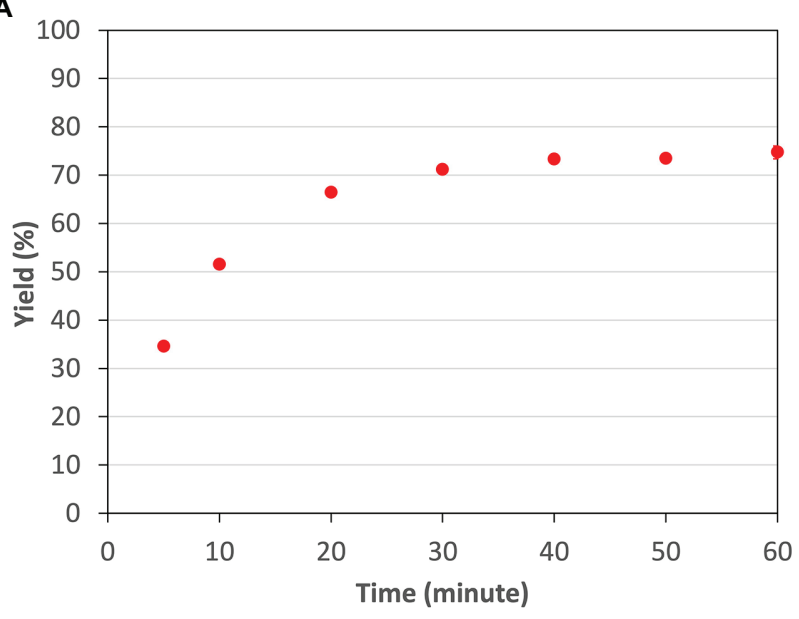

B

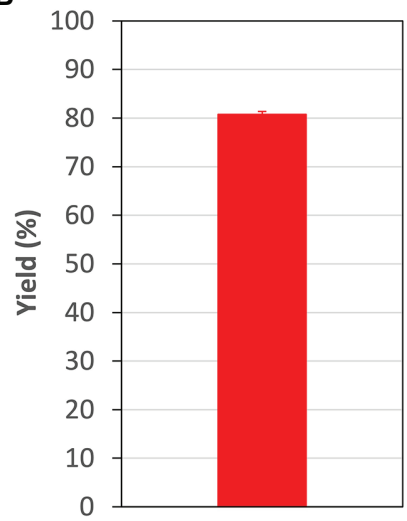

1 M fumarate

FIGURE 7 | The yield of L-malate obtained from fumarate hydration catalyzed by CmFUM. (A) The yield of L-malate when using 200 mM fumarate as a substrate. The concentration of $\mathrm{CmFum}$ was $1 \mu \mathrm{M}$. The measurement was performed at $52^{\circ} \mathrm{C}$ and $\mathrm{pH} 7.5$. (B) The yield of L-malate when using $1 \mathrm{M}$ fumarate as a substrate. The concentration of $\mathrm{CmFum}$ was $0.5 \mu \mathrm{M}$. The measurement was performed at $52^{\circ} \mathrm{C}$ and $\mathrm{pH} 7.5$ for $24 \mathrm{~h}$. All the data in Figure 7 show the mean $\pm \mathrm{SD}$ obtained from three independent experiments.

Fums from A. thaliana (mitochondrial Fum; Zubimendi et al., 2018) and Synechocystis 6803 (Katayama et al., 2019), there was a significant difference between the optimum $\mathrm{pH}$ for fumarate hydration and L-malate dehydration in CmFUM and TeFum (particularly CmFUM; Figures 2B,D). Therefore, we can regulate the equilibrium of the reaction catalyzed by $C m$ FUM by adjusting the $\mathrm{pH}$. This property would be beneficial for $\mathrm{L}$-malate production using fumarase.

Like Class II Fums from other organisms (A. thaliana, Synechocystis 6803, C. glutamicum, and H. sapience; Genda et al., 2006;
Zubimendi et al., 2018; Ajalla Aleixo et al., 2019; Katayama et al., 2019), CmFUM and TeFum preferentially catalyze fumarate hydration rather than L-malate dehydration (Table 1). The $K_{\mathrm{m}}$ of CmFUM $(0.27 \mathrm{mM})$ and TeFum $(0.14 \mathrm{mM})$ for fumarate were within the range of most Class II enzymes $(0.03-3.07 \mathrm{mM}$, nine species: E. coli, C. glutamicum, R. oryzae, Synechocystis 6803, S. cerevisiae, S. solfataricus, A. thaliana, T. thermophilus, and H. sapience; Woods et al., 1988; Puchegger et al., 1990; Keruchenko et al., 1992; Mizobata et al., 1998; Song et al., 2011; Lin et al., 2018; Zubimendi et al., 2018; Ajalla Aleixo et al., 2019; 
Katayama et al., 2019; Table 1). The $k_{\text {cat }}$ of CmFUM (235 s $\left.\mathrm{s}^{-1}\right)$ and TeFum $\left(37 \mathrm{~s}^{-1}\right)$ for fumarate were within the range of Class II Fums (21-513 $\mathrm{s}^{-1}$, four species: C. glutamicum, Synechocystis 6803, A. thaliana, and H. sapience, Lin et al., 2018; Zubimendi et al., 2018; Ajalla Aleixo et al., 2019; Katayama et al., 2019; Table 1). The $k_{\text {cat }} / K_{\mathrm{m}}$ of $\operatorname{CmFUM}\left(872 \mathrm{~s}^{-1} \mathrm{mM}^{-1}\right)$ for fumarate was similar to that of Class II Fum from $H$. sapience (850 s $\mathrm{s}^{-1} \mathrm{mM}^{-1}$; Ajalla Aleixo et al., 2019), and higher than those of cyanobacterial Class II Fums (Synechocystis 6803: $415 \mathrm{~s}^{-1} \mathrm{mM}^{-1}$, TeFum: $278 \mathrm{~s}^{-1} \mathrm{mM}^{-1}$; Katayama et al., 2019) and Class II Fums from C. glutamicum $\left(247 \mathrm{~s}^{-1} \mathrm{mM}^{-1}\right.$; Lin et al., 2018) and $A$. thaliana $\left(30 \mathrm{~s}^{-1} \mathrm{mM}^{-1}\right.$; Zubimendi et al., 2018; Table 1). Thus, CmFUM shows high catalytic activity for fumarate hydration. Phylogenetic analysis of biochemically characterized Class II Fums revealed that the catalytic activities of closely related enzymes are not necessarily conserved (Figure 8). This suggests that some amino acid residues and motifs affect the activities of Class II Fums. A SS loop, a motif contributing to substrate binding and catalytic activity (Puthan Veetil et al., 2012) was highly conserved in Class II Fums (Figure 9). In contrast, a combination of a total of three amino acid residues that contribute to the activities of Class II Fums from S. coelicolor (equivalent to position 257 and 441 of CmFUM; Lin et al., 2007) and Synechocystis 6803 (equivalent to position 401 of CmFUM; Katayama et al., 2019) was different for each Class II Fum (Figure 9). This combination of the three amino acid residues might bring diversity to the catalytic activities of Class II Fums and contribute to the high catalytic activity of $C m$ FUM. Unlike higher plants and algae, C. merolae do not possess an $\mathrm{NAD}^{+}$-dependent malic enzyme in mitochondria, so that the pyruvate transport to mitochondria is essential to perform aerobic respiration (Kuroiwa et al., 2017). The respiratory oxygen consumption of C. merolae drastically increases when not organic acids in the TCA cycle such as L-malate but pyruvate is added to the cells as an exogenous substrate (Moriyama et al., 2015). This suggests that the pyruvate generation in glycolysis is a rate-limiting step of the aerobic respiration and the TCA cycle in C. merolae actively works for energy production unlike that in cyanobacteria (Wan et al., 2017). The high catalytic activity of CmFUM supports this hypothesis.

Similar to Class II Fums from higher plants (Zubimendi et al., 2018) and Synechocystis 6803 (Katayama et al., 2019), both $\mathrm{CmFUM}$ and TeFum were inhibited by succinate and citrate (Figure 4), suggesting a common mechanism of inhibition of Class II Fums from photosynthetic organisms. In contrast, Class II Fum from C. glutamicum is not inhibited by succinate and citrate (Genda et al., 2006). Analyses of the effects of pyruvate on the activities for fumarate and L-malate revealed that pyruvate moves the equilibrium of the reaction catalyzed by $\mathrm{CmFUM}$ and TeFum to L-malate dehydration and fumarate hydration, respectively (Figure 4). Pyruvate also moves the

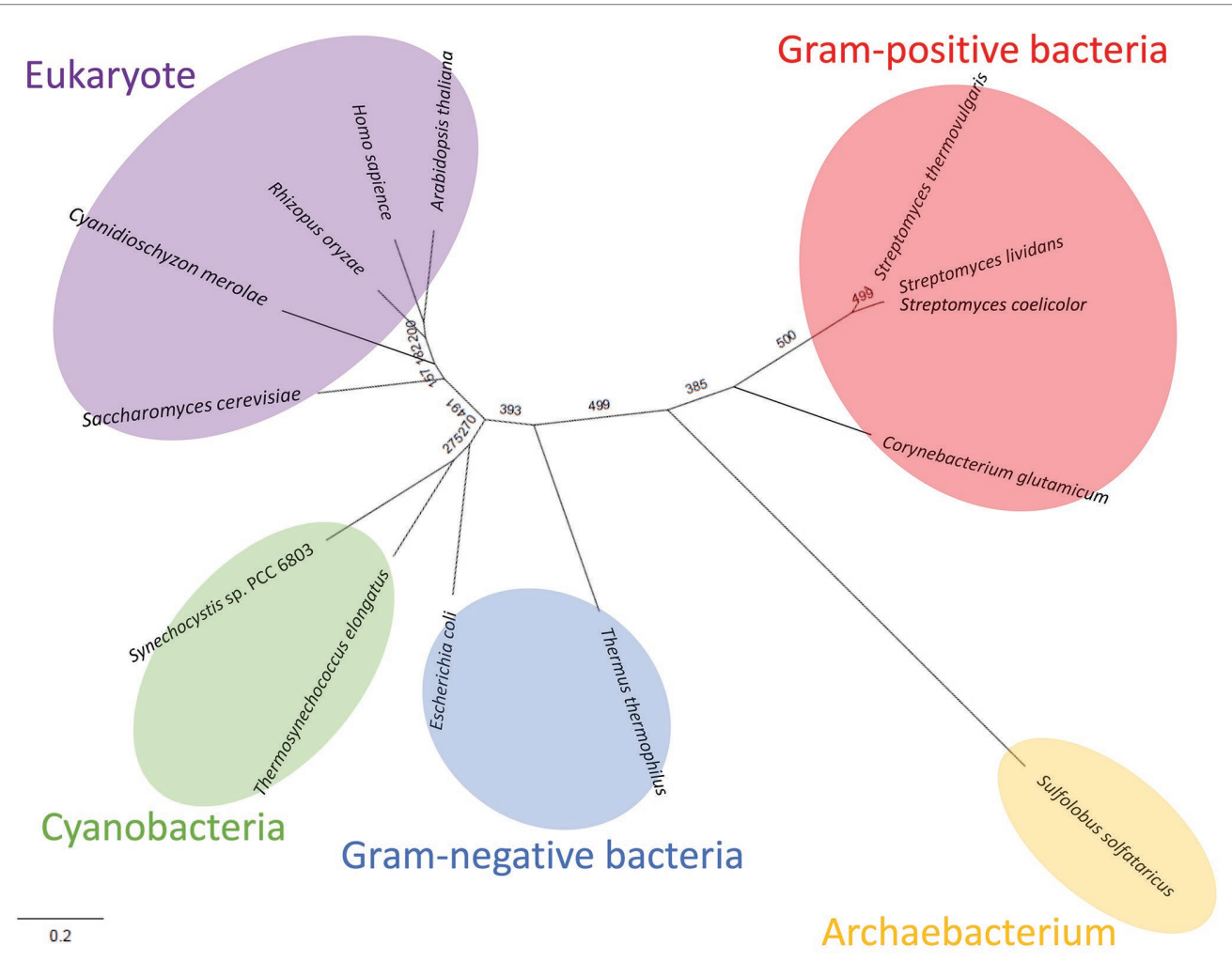

FIGURE 8 | Phylogenetic analysis of biochemically characterized Class II Fums. Sequence alignment of 14 Class II Fums was performed using CLC Sequence Viewer ver. 8.0. A phylogenetic tree was generated by maximum likelihood method based on 423 conserved amino acid residues using PhyML online (http://www.atgc-montpellier.fr/phyml/). Bootstrap value obtained by 500 replications indicates the reliability of each branch. 


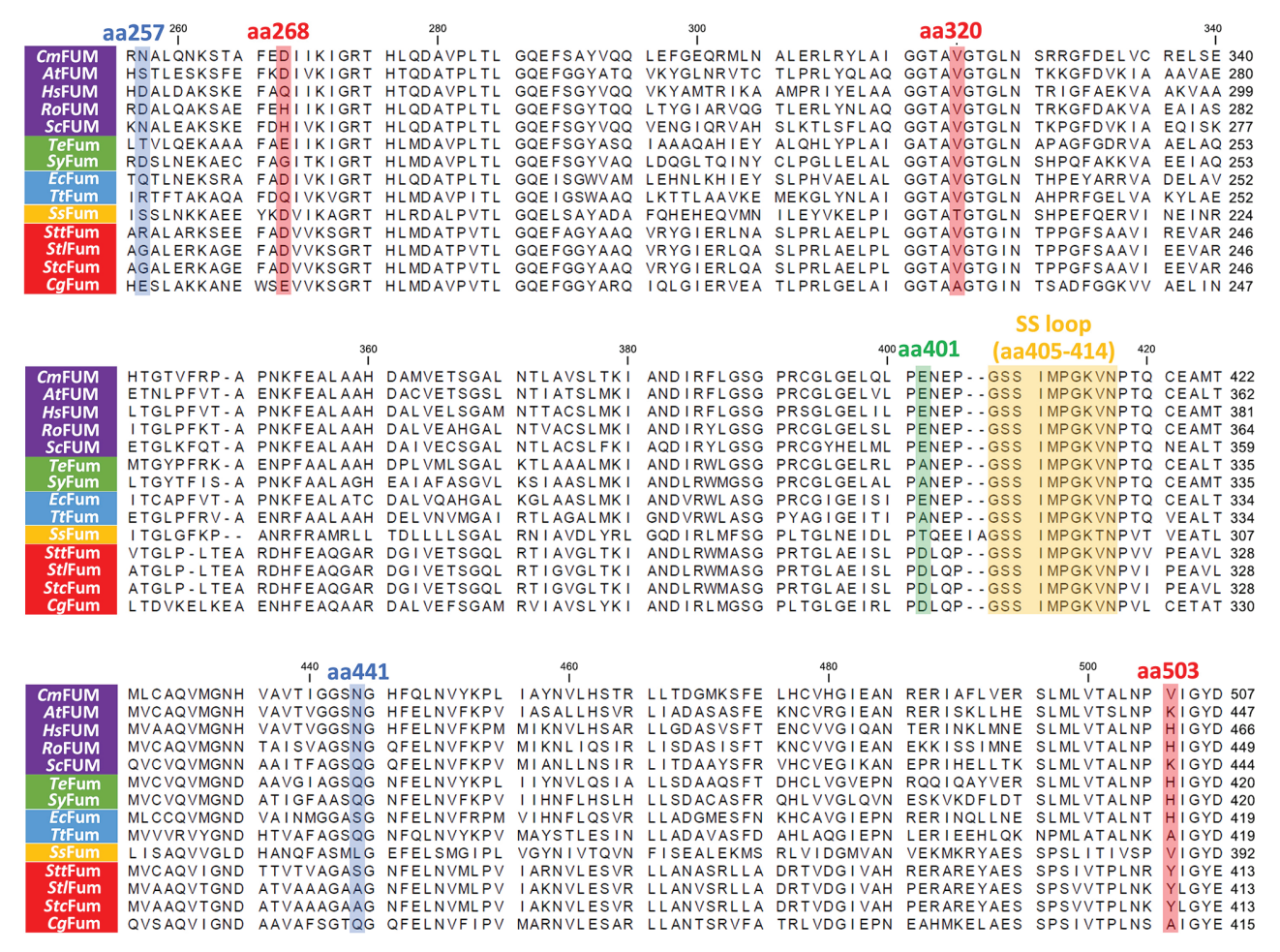

FIGURE 9 | Amino acid sequence comparison of biochemically characterized Class II Fums. Sequences of 14 Class II Fums were obtained from GenBank and aligned using CLC Sequence Viewer ver. 8.0. The blue squares represent amino acid residues equivalent to position 257 and 441 of $\mathrm{CmFUM}$ which contribute to the activity of Class II Fum from S. coelicolor (Lin et al., 2007). The green square represents an amino acid residue equivalent to position 401 of $\mathrm{CmFUM}$ which contributes to the activity of Class II Fum from Synechocystis 6803 (Katayama et al., 2019). The red squares represent amino acid residues equivalent to position 268, 320, and 503 of CmFUM which contribute to the thermostability of Class II Fum from C. glutamicum (Lin et al., 2018). The yellow square represents a loop region containing the sequence GSSxxPxKxN (called a SS loop) which contributes to substrate binding and catalytic activity (Puthan Veetil et al., 2012). AtFUM: Class II Fum from A. thaliana, HsFUM: Class II Fum from H. sapience, RoFUM: Class II Fum from R. oryzae, ScFUM: Class II Fum from S. cerevisiae, SyFum: Class II Fum from Synechocystis 6803, EcFum: Class II Fum from E. coli, TtFum: Class II Fum from T. thermophilus, SsFum: Class II Fum from S. solfataricus, SttFum: Class II Fum from S. thermovulgaris, StIFum: Class II Fum from S. lividans, StcFum: Class II Fum from S. coelicolor, CgFum: Class II Fum from C. glutamicum.

equilibrium of the reaction catalyzed by Class II Fums from A. thaliana (mitochondrial Fum) and Synechocystis 6803 to L-malate dehydration and fumarate hydration, respectively (Zubimendi et al., 2018; Katayama et al., 2019). Phylogenetic analysis of biochemically characterized Class II Fums revealed that eukaryotic Class II Fums form an independent cluster, not including cyanobacterial Class II Fums (Figure 8). These suggest that pyruvate affects the equilibrium of the reaction catalyzed by Class II Fums from photosynthetic organisms and the effects are different between Class II Fums from photosynthetic eukaryotes and cyanobacteria. The difference in metabolism and physiological characteristics between photosynthetic eukaryotes and cyanobacteria might be associated with the effects of pyruvate on their Class II Fums.

Additional biochemical analyses of $C m F U M$ clarified whether this enzyme has suitable enzymatic properties for efficient L-malate production. The $T_{50}{ }^{15}$ of $\mathrm{CmFUM}\left(57.3^{\circ} \mathrm{C}\right)$ was higher than both the Class II Fum from C. glutamicum $\left(44.8^{\circ} \mathrm{C}\right)$ as well as its thermostable mutant $\left(54.6^{\circ} \mathrm{C}\right.$; Lin et al., 2018; Figure 5A). Moreover, the $t_{1 / 2}$ at $50^{\circ} \mathrm{C}$ of the Class II Fum from C. glutamicum is $1 \mathrm{~min}$ (Lin et al., 2018), and the Class II
Fums from S. cerevisiae and S. coelicolor are immediately denatured at $50^{\circ} \mathrm{C}$ (Keruchenko et al., 1992; Lin et al., 2007). Class II Fum from $S$. thermovulgaris shows higher thermostability than these mesophilic Class II Fums and its $t_{1 / 2}$ at $50^{\circ} \mathrm{C}$ is $300 \mathrm{~min}$ (Lin et al., 2007). CmFum showed higher thermostability than the Class II Fum from $S$. thermovulgaris and its $t_{1 / 2}$ at $50^{\circ} \mathrm{C}$ of $\mathrm{CmFUM}$ was $507 \mathrm{~min}$ (Figure 5B). These suggest that $\mathrm{CmFUM}$ can show high activity after heat treatment in L-malate production. Phylogenetic analysis of biochemically characterized Class II Fums revealed that as well as the catalytic activities, and the thermostability of closely related enzymes is not necessarily conserved (Figure 8). In the Class II Fum from C. glutamicum, three amino acid residues equivalent to position 268, 320, and 503 of $\mathrm{CmFUM}$ contribute to the thermostability (Lin et al., 2018; Figure 9). Amino acid substitution equivalent to position 320 and 503 of $\mathrm{CmFUM}$ to valine enhances the thermostability of the Class II Fum from C. glutamicum (Lin et al., 2018). This suggests that the valine at position 320 and 503 of $\mathrm{CmFum}$ contribute to the high thermostability of $\mathrm{CmFUM}$ (Figure 9). In the Class II Fum from Synechocystis 6803, the activity for fumarate decreased 
in the presence of $\mathrm{Na}^{+}$(Katayama et al., 2019). However, CmFUM activity for fumarate did not change in the presence of monovalent and divalent metal cations (Figure 6A). In industrial L-malate production using fumarase, fumarate salts exist as sodium and calcium salts, which are easy to dissolve in water and do not affect the $\mathrm{pH}$ of the reaction and thus, can be used as fumarase substrates (Terasawa et al., 1990). CmFUM, which is insensitive to metal cations, can use these fumarate salts as substrates. CmFUM consistently showed enzymatic activity in four buffer solutions except for the HEPES$\mathrm{NaOH}$ buffer (Figure 6B). Considering the costs of the buffer solutions, we believe that Tris- $\mathrm{HCl}$ is a suitable buffer for $C m$ FUM. The yield of L-malate when using CmFUM (75-81\%) was higher than the yields when using Class II Fums from C. glutamicum (Chibata et al., 1987) and T. thermophilus (Ninh et al., 2013; Both are 70\%; Figure 7). The yield of L-malate when using Class II Fum from $R$. oryzae is expected to be $75-80 \%$ (Naude and Nicol, 2018).

In this study, we characterized the biochemical properties of Class II Fums from a thermophilic microalga and cyanobacterium. We demonstrated that $C m$ FUM has suitable enzymatic properties for efficient L-malate production such as high activity and thermostability. The optimizations of L-malate production using $C m$ FUM such as the utilization of a wholecell biocatalyst and reactor will be future developments.

\section{DATA AVAILABILITY STATEMENT}

The raw data supporting the conclusions of this article will be made available by the authors, without undue reservation.

\section{REFERENCES}

Ajalla Aleixo, M. A., Rangel, V. L., Rustiguel, J. K., de Pádua, R. A. P., and Nonato, M. C. (2019). Structural, biochemical and biophysical characterization of recombinant human fumarate hydratase. FEBS J. 286, 1925-1940. doi: 10.1111/febs.14782

Chibata, I., Tosa, T., and Yamamoto, K. (1987). Production of L-malic acid by immobilized microbial cells. Methods Enzymol. 136, 455-463. doi: 10.1016/ S0076-6879(87)36043-4

Coleman, J. R., and Colman, B. (1981). Inorganic carbon accumulation and photosynthesis in a blue-green alga as a function of external pH. Plant Physiol. 67, 917-921. doi: 10.1104/pp.67.5.917

Genda, T., Watabe, S., and Ozaki, H. (2006). Purification and characterization of fumarase from Corynebacterium glutamicum. Biosci. Biotechnol. Biochem. 70, 1102-1109. doi: 10.1271/bbb.70.1102

Katayama, N., Takeya, M., and Osanai, T. (2019). Biochemical characterisation of fumarase $\mathrm{C}$ from a unicellular cyanobacterium demonstrating its substrate affinity, altered by an amino acid substitution. Sci. Rep. 9:10629. doi: 10.1038/ s41598-019-47025-7

Keruchenko, J. S., Keruchenko, I. D., Gladilin, K. L., Zaitsev, V. N., and Chirgadze, N. Y. (1992). Purification, characterization and preliminary X-ray study of fumarase from Saccharomyces cerevisiae. Biochim. Biophys. Acta 1122, 85-92. doi: 10.1016/0167-4838(92)90131-V

Kuroiwa, T., Kuroiwa, H., Sakai, A., Takahashi, H., Toda, K., and Itoh, R. (1998). The division apparatus of plastids and mitochondria. Int. Rev. Cytol. 181, 1-41. doi: 10.1016/S0074-7696(08)60415-5

Kuroiwa, T., Miyagishima, S. Y., Matsunaga, S., Sato, N., Nozaki, H., and Tanaka, K. K., et al. (eds.) (2017). Cyanidioschyzon merolae: A new model eukaryote for cell and organelle biology. Heidelberg, Germany: Springer.

\section{AUTHOR CONTRIBUTIONS}

SI designed the study, analyzed the data, and wrote the manuscript. KI and HS performed the experiments and analyzed the data. TO designed the study and wrote the manuscript. All authors contributed to the article and approved the submitted version.

\section{FUNDING}

This work was supported by the Ministry of Education, Culture, Sports, Science, and Technology, Japan, by a grant to TO from ALCA from the Japan Science and Technology Agency [grant number JPMJAL1306] and JSPS KAKENHI Grant-in-Aid for Scientific Research on Innovative Areas [grant number 16H06559].

\section{ACKNOWLEDGMENTS}

The language of the manuscript has been corrected by Editage Co. Ltd.

\section{SUPPLEMENTARY MATERIAL}

The Supplementary Material for this article can be found online at: https://www.frontiersin.org/articles/10.3389/fmicb.2020.560894/ full\#supplementary-material

Laughlin, T. G., Bayne, A. N., Trempe, J. F., Savage, D. F., and Davies, K. M (2019). Structure of the complex I-like molecule NDH of oxygenic photosynthesis. Nature 566, 411-414. doi: 10.1038/s41586-019-0921-0

Lin, W., Chan, M., Goh, L. L., and Sim, T. S. (2007). Molecular basis for thermal properties of Streptomyces thermovulgaris fumarase C hinge at hydrophilic amino acids R163, E170 and S347. Appl. Microbiol. Biotechnol. 75, 329-335. doi: 10.1007/s00253-006-0822-7

Lin, L., Wang, Y., Wu, M., Zhu, L., Yang, L., and Lin, J. (2018). Enhancing the thermostability of fumarase C from Corynebacterium glutamicum via molecular modification. Enzym. Microb. Technol. 115, 45-51. doi: 10.1016/j. enzmictec.2018.04.010

Liu, J., Li, J., Shin, H. D., Du, G., Chen, J., and Liu, L. (2017). Biological production of L-malate: recent advances and future prospects. World J. Microbiol. Biotechnol. 34:6. doi: 10.1007/s11274-017-2349-8

Mangan, N. M., Flamholz, A., Hood, R. D., Milo, R., and Savage, D. F. (2016). $\mathrm{pH}$ determines the energetic efficiency of the cyanobacterial $\mathrm{CO}_{2}$ concentrating mechanism. Proc. Natl. Acad. Sci. U. S. A. 113, E5354-E5362. doi: 10.1073/ pnas. 1525145113

Matsuzaki, M., Misumi, O., Shin-I, T., Maruyama, S., Takahara, M., Miyagishima, S. Y., et al. (2004). Genome sequence of the ultrasmall unicellular red alga Cyanidioschyzon merolae 10D. Nature 428, 653-657. doi: 10.1038/nature02398

Mizobata, T., Fujioka, T., Yamasaki, F., Hidaka, M., Nagai, J., and Kawata, Y. (1998). Purification and characterization of a thermostable class II fumarase from Thermus thermophilus. Arch. Biochem. Biophys. 355, 49-55. doi: 10.1006/ abbi.1998.0693

Moriyama, T., Mori, N., and Sato, N. (2015). Activation of oxidative carbon metabolism by nutritional enrichment by photosynthesis and exogenous organic compounds in the red alga Cyanidioschyzon merolae: evidence for heterotrophic growth. Springerplus 4:559. doi: 10.1186/s40064-015-1365-0 
Moriyama, T., Terasawa, K., Fujiwara, M., and Sato, N. (2008). Purification and characterization of organellar DNA polymerases in the red alga Cyanidioschyzon merolae. FEBS J. 275, 2899-2918. doi: 10.1111/ j.1742-4658.2008.06426.x

Murray, J. W., Maghlaoui, K., and Barber, J. (2007). The structure of allophycocyanin from Thermosynechococcus elongatus at $3.5 \AA$ resolution. Acta Crystallogr. Sect. F Struct. Biol. Commun. 63, 998-1002. doi: 10.1107/S1744309107050920

Nakamura, Y., Kaneko, T., Sato, S., Ikeuchi, M., Katoh, H., Sasamoto, S., et al. (2002). Complete genome structure of the thermophilic cyanobacterium Thermosynechococcus elongatus BP-1. DNA Res. 9, 123-130. doi: 10.1093/ dnares/9.4.123

Naude, A., and Nicol, W. (2018). Malic acid production through the whole-cell hydration of fumaric acid with immobilised Rhizopus oryzae. Biochem. Eng. J. 137, 152-161. doi: 10.1016/j.bej.2018.05.022

Ninh, P. H., Honda, K., Yokohigashi, Y., Okano, K., Omasa, T., and Ohtake, H. (2013). Development of a continuous bioconversion system using a thermophilic whole-cell biocatalyst. Appl. Environ. Microbiol. 79, 1996-2001. doi: 10.1128/ AEM.03752-12

Nozaki, H., Takano, H., Misumi, O., Terasawa, K., Matsuzaki, M., Maruyama, S., et al. (2007). A 100\%-complete sequence reveals unusually simple genomic features in the hot-spring red alga Cyanidioschyzon merolae. BMC Biol. 5:28. doi: 10.1186/1741-7007-5-28

Ohta, N., Matsuzaki, M., Misumi, O., Miyagishima, S. Y., Nozaki, H., Tanaka, K., et al. (2003). Complete sequence and analysis of the plastid genome of the unicellular red alga Cyanidioschyzon merolae. DNA Res. 10, 67-77. doi: 10.1093/dnares/10.2.67

Ohta, N., Sato, N., and Kuroiwa, T. (1998). Structure and organization of the mitochondrial genome of the unicellular red alga Cyanidioschyzon merolae deduced from the complete nucleotide sequence. Nucleic Acids Res. 26, 5190-5198. doi: 10.1093/nar/26.22.5190

Osanai, T., Shirai, T., Iijima, H., Nakaya, Y., Okamoto, M., Kondo, A., et al. (2015). Genetic manipulation of a metabolic enzyme and a transcriptional regulator increasing succinate excretion from unicellular cyanobacterium. Front. Microbiol. 6:1064. doi: 10.3389/fmicb.2015.01064

Patel, A., Matsakas, L., Rova, U., and Christakopoulos, P. (2019). A perspective on biotechnological applications of thermophilic microalgae and cyanobacteria. Bioresour. Technol. 278, 424-434. doi: 10.1016/j.biortech.2019.01.063

Puchegger, S., Redl, B., and Stöffler, G. (1990). Purification and properties of a thermostable fumarate hydratase from the archaeobacterium Sulfolobus solfataricus. J. Gen. Microbiol. 136, 1537-1541. doi: 10.1099/00221287-136-8-1537

Puthan Veetil, V., Fibriansah, G., Raj, H., Thunnissen, A. M., and Poelarends, G. J. (2012). Aspartase/fumarase superfamily: a common catalytic strategy involving general base-catalyzed formation of a highly stabilized aci-carboxylate intermediate. Biochemistry 51, 4237-4243. doi: 10.1021/bi300430j

Sacchettini, J. C., Frazier, M. W., Chiara, D. C., Banaszak, L. J., and Grant, G. A. (1988). Amino acid sequence of porcine heart fumarase. Biochem. Biophys. Res. Commun. 153, 435-440. doi: 10.1016/S0006-291X(88)81243-9

Schuller, J. M., Birrell, J. A., Tanaka, H., Konuma, T., Wulfhorst, H., Cox, N., et al. (2019). Structural adaptations of photosynthetic complex I enable ferredoxin-dependent electron transfer. Science 363, 257-260. doi: 10.1126/ science.aau3613

Song, P., Li, S., Ding, Y., Xu, Q., and Huang, H. (2011). Expression and characterization of fumarase (FUMR) from Rhizopus oryzae. Fungal Biol. 11, 49-53. doi: 10.1016/j.funbio.2010.10.003

Su, R. R., Wang, A., Hou, S. T., Gao, P., Zhu, G. P., and Wang, W. (2014). Identification of a novel fumarase C from Streptomyces lividans TK54 as a good candidate for L-malate production. Mol. Biol. Rep. 41, 497-504. doi: $10.1007 /$ s11033-013-2885-8

Takata, I., Tosa, T., and Chibata, I. (1983). Stabilization of fumarase activity of Brevibacterium flavum cells by immobilization with $\mathrm{K}$-carrageenan. Appl. Biochem. Biotechnol. 8, 31-38. doi: 10.1007/BF02798346

Takeya, M., Hirai, M. Y., and Osanai, T. (2017). Allosteric inhibition of phosphoenolpyruvate carboxylases is determined by a single amino acid residue in cyanobacteria. Sci. Rep. 7:41080. doi: 10.1038/srep41080

Terasawa, M, Nara, T, Yukawa, H, Yamagata, H, and Satoo, Y (1990). Method of preparing l-malic acid. U.S. Patent No 4,912,043.

Wan, N., DeLorenzo, D. M., He, L., You, L., Immethun, C. M., Wang, G., et al. (2017). Cyanobacterial carbon metabolism: fluxome plasticity and oxygen dependence. Biotechnol. Bioeng. 114, 1593-1602. doi: 10.1002/bit.26287

Woods, S. A., Schwartzbach, S. D., and Guest, J. R. (1988). Two biochemically distinct classes of fumarase in Escherichia coli. Biochim. Biophys. Acta 954, 14-26. doi: 10.1016/0167-4838(88)90050-7

Yamaoka, T., Satoh, K., and Katoh, S. (1978). Photosynthetic activities of a thermophilic blue-green alga. Plant Cell Physiol. 19, 943-954. doi: 10.1093/ oxfordjournals.pcp.a075684

Zenvirth, D., Volokita, M., and Kaplan, A. (1985). Photosynthesis and inorganic carbon accumulation in the acidophilic alga Cyanidioschyzon merolae. Plant Physiol. 77, 237-239. doi: 10.1104/pp.77.1.237

Zhang, S., Heyes, D. J., Feng, L., Sun, W., Johannissen, L. O., Liu, H., et al. (2019). Structural basis for enzymatic photocatalysis in chlorophyll biosynthesis. Nature 574, 722-725. doi: 10.1038/s41586-019-1685-2

Zubimendi, J. P., Martinatto, A., Valacco, M. P., Moreno, S., Andreo, C. S., Drincovich, M. F., et al. (2018). The complex allosteric and redox regulation of the fumarate hydratase and malate dehydratase reactions of Arabidopsis thaliana Fumarase 1 and 2 gives clues for understanding the massive accumulation of fumarate. FEBS J. 285, 2205-2224. doi: 10.1111/febs.14483

Conflict of Interest: The authors declare that the research was conducted in the absence of any commercial or financial relationships that could be construed as a potential conflict of interest.

Copyright (c) 2020 Ito, Iwazumi, Sukigara and Osanai. This is an open-access article distributed under the terms of the Creative Commons Attribution License (CC BY). The use, distribution or reproduction in other forums is permitted, provided the original author(s) and the copyright owner(s) are credited and that the original publication in this journal is cited, in accordance with accepted academic practice. No use, distribution or reproduction is permitted which does not comply with these terms. 